\title{
PENINGKATAN KEMAMPUAN PEMECAHAN MASALAH MATEMATIKA MELALUI PENERAPAN PROBLEM BASED LEARNING UNTUK SISWA KELAS V SD
}

\author{
Desi Indarwati \\ Alumni Program Studi S1 Pendidikan Matematika \\ FKIP Universitas Kristen Satya Wacana \\ Wahyudi \\ Program Studi S1 Pendidikan Guru Sekolah Dasar (PGSD) \\ FKIP Universitas Kristen Satya Wacana \\ Novisita Ratu \\ Program Studi S1 Pendidikan Matematika \\ FKIP Universitas Kristen Satya Wacana
}

\begin{abstract}
ABSTRAK
Tujuan penelitian ini adalah untuk meningkatkan kemampuan pemecahan masalah operasi hitung bilangan pecahan melalui penerapan Problem Based Learning pada siswa kelas V SDN Mlowo Karagtalun 04 Kecamatan Pulokulon Kabupaten Grobogan. Kemampuan siswa dalam pemecahan masalah operasi hitung bilangan pecahan masih banyak yang di bawah $\mathrm{KKM} \geq 65$. Hal itu dikarenakan guru masih menggunakan metode yang menekankan penggunaan rumus dan latihan soal yang bersifat rutin. Oleh sebab itu, peneliti berupaya untuk meningkatkan kemampuan pemecahan masalah siswa melalui penerapan Problem Based Learning. Penelitian ini adalah penelitian tindakan kelas, yang terdiri dari dua siklus. Masing-masing siklus terdiri dari tiga tahapan yaitu perencanaan, pelaksanaan dan observasi, refleksi.Penelitian ini dilakukan di SDN Mlowo Karangtalun Kecamatan Pulokulon Kabupaten Grobogan dengan subjek penelitian siswa kelas V. Teknik pengumpulan data yang dilakukan pada penelitian ini adalah tes dan observasi.Instrumen yang digunakan adalah soal tes, lembar observasi aktivitas siswa dan guru. Data yang diperoleh meliputi data kemampuan pemecahan masalahoperasi hitung bilangan pecahan, data hasil observasi proses pembelajaran dari aktivitas guru dan siswa. Analisis data dilakukan dengan menggunakan analisis deskriptif komparatif yaitu dengan membandingkan hasil pra siklus, hasil siklus 1, dan siklus 2. Indikator keberhasilan pada penelitian ini adalah 85 persen siswa tuntas dengan $\mathrm{KKM} \geq 65$. Hasil penelitian menunjukkan bahwa penerapan Problem Based Learning dapat meningkatkan kemampuan pemecahan masalah operasi hitung bilangan pecahan.Terjadi peningkatan nilai rata-rata kelas dari 62,87 pada pra siklus menjadi 74,96 pada siklus 1 dan 84,43 pada siklus 2. Jumlah siswa yang tuntas belajar meningkat dari 9 siswa (39\%) pada pra siklus menjadi17 siswa (74\%) pada siklus 1 dan 20 siswa (87\%) siswa tuntas pada siklus 2. Penelitian ini berhasil karena sudah mencapai indikator keberhasilan yaitu 85 persen siswa tuntas belajar dengan $\mathrm{KKM} \geq 65$.
\end{abstract}

Kata Kunci: kemampuan pemecahan masalah, problem based learning, pecahan, matematika, Sekolah Dasar 


\section{PENDAHULUAN}

Menurut Permendiknas RI No. 19 tahun 2005 tentang Standar Nasional Pendidikan pasal 1 No. 14, mata pelajaran matematika bertujuan agar siswa memiliki kemampuan sebagai berikut: (1) Memahami konsep matematika, menjelaskan keterkaitan antarkonsep dan mengaplikasikan konsep atau algoritma, secara luwes, akurat, efisien, dan tepat, dalam pemecahan masalah, (2) Menggunakan penalaran pada pola dan sifat, melakukan manipulasi matematika dalam membuat generalisasi, menyusun bukti, atau menjelaskan gagasan dan pernyataan matematika, (3) Memecahkan masalah yang meliputi kemampuan memahami masalah, merancang model matematika, menyelesaikan model dan menafsirkan solusi yang diperoleh, (4) Mengomunikasikan gagasan dengan simbol, tabel, diagram, atau media lain untuk memperjelas keadaan atau masalah, (5) Memiliki sikap menghargai kegunaan matematika dalam kehidupan, yaitu memiliki rasa ingin tahu, perhatian, dan minat dalam mempelajari matematika, serta sikap ulet dan percaya diri dalam pemecahan masalah.

Tujuan pembelajaran matematika yang tercantum dalam Permendiknas RI No. 19 tahun 2005 tentang Standar Nasional Pendidikan pasal 1 No. 14 rasanya akan sulit tercapai apabila guru masih menerapkan pembelajaran ekspositori, yaitu menekankan pada penggunaan rumus dan latihan soal (Hamid, 2011). Pembelajaran ekspositori juga sulit untuk memungkinkan siswa mengembangkan kecakapan berpikir, kecakapan interpersonal, kecakapan beradaptasi dengan baik, karena dalam pembelajaran ekspositori guru lebih banyak mendominasi aktivitas kelas dan latihan-latihan yang diberikan bersifat rutin serta siswa bersifat pasif dalam proses belajar sehingga kemampuan siswa dalam pemecahan masalah masih kurang (Amir, 2010).

Matematika adalah ilmu yang abstrak dan deduktif, sedangkan siswa SD yang berusia pada usia 7 hingga 12 tahun masih berada pada tahap operasional konkrit yang belum dapat berpikir formal (UPI, 2007). Operasi hitung bilangan pecahan merupakan bidang kajian matematika yang menjadi masalah bagi siswa sekolah dasar, termasuk siswa kelas V SDN Mlowo Karangtalun 04 Kecamatan Pulokulon Kabupaten Grobogan. Berdasarkan data yang didapat dari guru kelas V SDN Mlowo Karangtalun 04 Kecamatan Pulo-kulon Kabupaten Grobogan, siswa yang tidak lulus ulangan harian operasi hitung bilangan pecahan sebanyak 14 siswa (61\%) dari 23 siswa dengan batas kriteria ketuntasan minimum 65. Siswa agar dapat meyelesaikan masalah operasi hitung bilangan pecahan, dituntut untuk berkemampuan memecahkan masalah. Siswa dapat berkemampuan memecahkan masalah apabila proses pembelajaran dilakukan dengan pembelajaran yang tepat. Pembelajaran yang memberi peluang kepada siswa mempunyai kemampuan memahami masalah secara baik, merumuskan pemecahan masalah, melakukan pemecahan masalah, meninjau kembali dan mengambil keputusan akhir alternatif pemecahan yang paling efektif.

Alternatif pembelajaran yang dapat memberi peluang untuk terciptanya kemampuan tersebut adalah Problem Based Learning. Problem Based Learning adalah metode pembelajaran yang dilandasi dengan sebuah persoalan sebagai stimulus belajar. Masalah diambil dari kejadian nyata dalam kehidupan nyata di sekitar siswa sehingga mudah untuk dipahami dan menarik untuk siswa. Arend (Trianto, 2009) mengemukakan bahwa salah satu kelebihan Problem Based Learning 
adalah meningkatkan kemampuan pemecahan masalah.

Tulisan ini akan memberikan gambaran bagaimana Problem Based Learning diterapkan dalam pembelajaran di sekolah dasar mulai dari perencanaan, implementasi dan bagaimana dampaknya terhadap kemampuan siswa dalam memecahkan masalah matematika.

\section{KAJIAN PUSTAKA}

\section{Masalah Matematika}

Terdapat beberapa pendapat tentang definisi masalah matematika. Grouws dalam Nuralam (2009) menyatakan bahwa masalah dalam matematika adalah segala sesuatu yang menghendaki untuk dikerjakan. Kata "segala sesuatu" dapat menunjukkan pertanyaan yang menghendaki suatu penyelesaian. Newell dan Simon dalam Nuralam (2009) juga mendefinisikan masalah sebagai sesuatu pertanyaan dimana seseorang ingin memecahkan pertanyaan tersebut tetapi dia tidak mengetahui secara serta merta bagaimana cara untuk menyelesaikannya.

Lidinillah (2009) mengemukakan bahwa masalah dalam pembelajaran matematika dapat disajikan dalam bentuk soal tidak rutin yang berupa soal cerita, penggambaran fenomena atau kejadian, ilustrasi gambar atau teka-teki. Masalah tersebut kemudian disebut masalah matematika karena mengandung konsep matematika. Terdapat beberapa jenis masalah matematika, walaupun sebenarnya tumpang tindih, tapi perlu dipahami oleh guru matematika ketika akan menyajikan soal matematika. Handoyo (Lidinillah, 2009), juga menyebutkan jenisjenis masalah matematika adalah sebagai berikut: (a) Masalah translasi, merupakan masalah kehidupan sehari-hari yang untuk menyelesaikannya perlu translasi dari bentuk verbal ke bentuk matematika, (b) Masalah aplikasi, memberikan kesempatan kepada siswa untuk menyelesaikan masalah dengan menggunakan berbagai macam-macam keterampilan dan prosedur matematika, (c) Masalah proses, biasanya untuk menyusun langkah-langkah merumuskan pola dan strategi khusus dalam menyelesaikan masalah. Masalah seperti ini dapat melatih keterampilan siswa dalam menyelesaikan masalah sehingga menjadi terbiasa menggunakan strategi tertentu, (d) Masalah teka-teki, seringkali digunakan untuk rekreasi dan kesenangan sebagai alat yang bermanfaat untuk tujuan afektif dalam pembelajaran matematika.

Dilihat dari sifatnya dan cara penyelesaiannya, masalah matematika dapat dibedakan atas masalah tertutup (closed-ended) dan masalah terbuka (open-ended). Masalah tertutup (closed-ended) adalah masalah yang dirumuskan sedemikian rupa sehingga hanya memiliki satu jawaban yang benar dengan satu pemecahannya, sedangkan masalah terbuka (open-ended)) adalah suatu permasalahan yang mempunyai banyak penyelesaian atau banyak cara untuk mendapatkan penyelesaian.

\section{Kemampuan Pemecahan Masalah Matematika}

Sumardiyono (Supinah, 2010) mengungkapkan bahwa pemecahan masalah adalah proses menerapkan pengetahuan yang telah diperoleh sebelumnya ke dalam situasi baru yang belum dikenal. Pemecahan masalah pada dasarnya adalah proses yang ditempuh oleh seseorang untuk menyelesaikan masalah yang dihadapinya sampai masalah itu tidak lagi menjadi masalah baginya (Hudojo, 1988).

Menurut Polya (Nuralam, 2009), pemecahan masalah merupakan suatu usaha untuk menemukan jalan keluar dari suatu 
kesulitan dan mencapai tujuan yang tidak dapat dicapai dengan segera. Pemecahan masalah merupakan proses bagaimana mengatasi suatu persoalan atau pertanyaan yang bersifat menantang yang tidak dapat diselesaikan dengan prosedur rutin yang sudah biasa dilakukan/sudah diketahui (Nazwandi, 2010). Krulik dan Rudnik (Lidinilah, 2009) juga mendefinisikan pemecahan masalah sebagai suatu usaha individu menggunakan pengetahuan, keterampilan dan pemahamannya untuk menemukan solusi dari suatu masalah. Sukmadinata dan As'ari (Lidinilah, 2009), menempatkan penyelesaian masalah pada tahapan berpikir tingkat tinggi setelah evaluasi dan sebelum kreativitas yang menjadi tambahan pada tahapan berpikir yang dikembangkan oleh Anderson dan Krathwohl.

Menurut Slavin (1994), pemecahan masalah merupakan penerapan dari pengetahuan dan keterampilan untuk mencapai tujuan dengan tepat. Demikian pemerolehan pengetahuan dan keterampilan dalam pemecahan masalah terjadi dari pengalamanpengalaman sebagai pengetahuan awal yang dapat disintesiskan. Lampiran Permendiknas No. 22 Tahun 2006 (Supinah, 2010) mengemukakan, bahwa pemecahan masalah merupakan fokus dalam pembelajaran matematika yang mencakup masalah tertutup dengan solusi tunggal, masalah terbuka dengan solusi tidak tunggal, dan masalah dengan berbagai cara penyelesaian.

Berdasarkan pendapat tersebut, maka dapat didefinisikan bahwa pemecahan masalah merupakan suatu usaha untuk menemukan jalan keluar dari suatu kesulitan dan mencapai tujuan yang tidak dapat dicapai dengan segera.

\section{Langkah-langkah Pemecahan Masalah}

Langkah-langkah pemecahan masalah menurut Polya (Nuralam, 2009) yakni memahami masalah, merencanakan penyelesaian, menyelesaikan masalah, dan melakukan pengecekan kembali semua langkah yang telah dikerjakan. Pada fase memahami masalah siswa tidak mungkin menyelesaikan masalah dengan benar tanpa adanya pemahaman terhadap masalah yang diberikan, selanjutnya siswa harus mampu menyusun rencana atau strategi. Penyelesaian masalah dalam fase ini sangat tergantung pada pengalaman siswa yang kreatif dalam menyusun penyelesaian suatu masalah. Langkah selanjutnya adalah siswa mampu menyelesaikan masalah sesuai dengan rencana yang telah disusun dan dianggap tepat. Langkah terakhir dari proses penyelesaian masalah menurut Polya adalah melakukan pengecekan atas apa yang dilakukan, mulai dari fase pertama hingga hingga fase ketiga. Kesalahan yang tidak perlu terjadi dapat dikoreksi kembali dengan model seperti ini, sehingga siswa dapat menemukan jawaban yang benar-benar sesuai dengan masalah yang diberikan.

Secara garis besar langkah-langkah pemecahan masalah menurut Polya dapat digambarkan seperti pada Gambar 1.

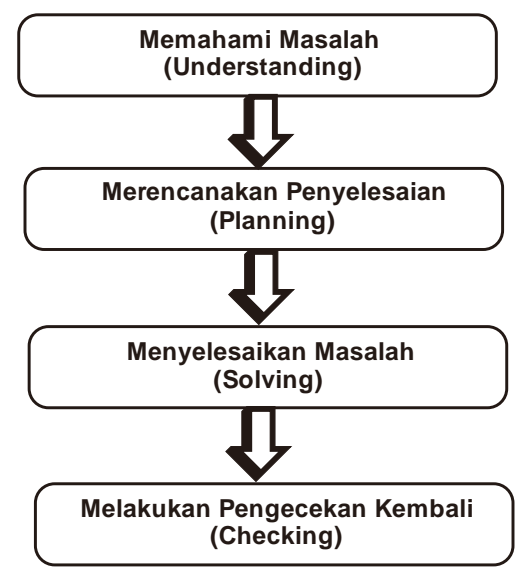

Gambar 1 Langkah-langkah pemecahan masalah menurut Polya 
Adapun penjabaran dari keempat langkah tersebut yang digunakan sebagai landasan dalam memecahkan suatu masalah pada penelitian ini dapat diuraikan sebagai berikut. Tahap pertama adalah tahap memahami soal (understanding). Pada tahap pemahaman soal, siswa harus dapat memahami kondisi soal atau masalah yang ada pada soal tersebut. Ciri-ciri siswa yang paham terhadap isi soal ialah siswa dapat mengungkapkan pertanyaan-pertanyaan beserta jawabannya seperti berikut: data atau informasi apa yang dapat diketahui dari soal?, apa inti permasalahan dari soal yang memerlukan pemecahan?, adakah dalam soal itu rumusrumus, gambar, grafik, tabel, atau tanda-tanda khusus?, adakah syarat-syarat penting yang perlu diperhatikan dalam soal?. Sasaran penilaian pada tahap pemahaman soal ini adalah siswa mampu menganalisis soal, hal ini dapat terlihat apakah siswa tersebut paham dan mengerti terhadap apa yang diketahui dan yang ditanyakan dalam soal, serta siswa dapat menuliskan apa yang diketahui dan apa yang ditanyakan dalam bentuk rumus, simbol, atau kata-kata sederhana.

Tahap kedua adalah tahap pemikiran suatu rencana (planning). Menurut Polya pada tahap pemikiran suatu rencana, siswa harus dapat memikirkan langkah-langkah apa saja yang penting dan saling menunjang untuk dapat memecahkan masalah yang dihadapinya. Kemampuan berpikir yang tepat hanya dapat dilakukan jika sebelumnya siswa telah dibekali dengan pengetahuan-pengetahuan yang cukup memadai dalam arti masalah yang dihadapi siswa bukan hal yang baru tetapi sejenis atau mendekati. Pada tahap ini siswa harus mencari konsep-konsep atau teori-teori yang saling menunjang dan mencari rumus-rumus yang diperlukan.

Tahap ketiga adalah pelaksanaan rencana (solving), yang dimaksud tahap pelaksanaan rencana ialah siswa telah siap melakukan perhitungan dengan segala macam data yang diperlukan termasuk konsep dan rumus atau persamaan yang sesuai. Pada tahap ini siswa harus dapat membentuk sistematika soal yang lebih baku, dalam arti rumus-rumus yang akan digunakan sudah merupakan rumus yang siap untuk digunakan sesuai dengan apa yang digunakan dalam soal, kemudian siswa mulai memasukkan data-data hingga menjurus ke rencana pemecahannya, setelah itu baru siswa melaksanakan langkah-langkah rencana sehingga akan diharapkan dari soal dapat dibuktikan atau diselesaikan.

Tahap terakhir adalah tahap peninjauan kembali (checking), yang diharapkan dari keterampilan siswa dalam memecahkan masalah untuk tahap ini adalah siswa harus berusaha mengecek ulang dan menelaah kembali dengan teliti setiap langkah pemecahan yang dilakukannya.

Wickelgren (Lidinilah, 2009) juga mengemukakan langkah-langkah pemecahan masalah. Langkah pemecahan masalah menurut Wickelgren ini merupakan perincian dari langkah pemecahan masalah menurut Polya yang terdiri dari 4 langkah pemecahan masalah, yaitu: menganalisis dan memahami masalah (analyzing and understanding a problem); merancang dan merencanakan solusi (designing and planning a solution); mencari solusi dari masalah (exploring solution to difficult problem); dan memeriksa solusi (verifying a solution). Berikut ini adalah rincian dari langkah-langkah tersebut: (a) Menganalisis dan memahami masalah (analyzing and understanding a problem). Membuat gambar atau ilustrasi jika memungkinkan, mencari kasus yang khusus. Mencoba memahami masalah secara sederhana, (b) Merancang dan merencanakan solusi (designing and planning a solution). Merencanakan 
solusi secara sistematis dan menentukan apa yang akan dilakukan. Bagaimana melakukannya serta hasil yang diharapkan, (c) Mencari solusi dari masalah (exploring solution to difficult problem). Menentukan berbagai masalah yang ekivalen, yaitu: penggantian kondisi dengan yang ekivalen; menyusun kembali bagian-bagian masalah dengan cara berbeda; menambah bagian yang diperlukan; serta memformulasikan kembali masalah. Menentukan dan melakukan memodifikasi secara lebih sederhana dari masalah sebenarnya, yaitu: memilih tujuan antara dan mencoba memecahkannya; mencoba lagi mencari solusi akhir; dan memecahkan soal secara bertahap. Menentukan dan melakukan memodifikasi secara umum dari masalah sebenarnya, yaitu: memecahkan masalah yang analog dengan variabel yang lebih sedikit; mencoba menyelesaikan dengan kondisi satu variabel; serta memecahkan masalah melalui masalah yang mirip, (d) Memeriksa solusi (verifying a solution). Menggunakan pemeriksaan secara khusus terhadap setiap informasi dan langkah penyelesaian.

Menggunakan pemeriksaan secara umum untuk mengetahui masalah secara umum dan pengembangannya.

Sedangkan menurut Schoenfeld (Goos et.al dalam Lidinilah, 2009) terdapat 5 langkah dalam memecahkan masalah, yaitu Reading, Analisys, Exploration, Planning/ Implementation, dan Verification. Artzt \& Armour-Thomas (Goos et.al dalam Lidinilah, 2009) telah mengembangkan langkahlangkah pemecahan masalah dari Schoenfeld, yaitu menjadi Reading, Understanding, Analisys, Exploration, Planning, Implementation, dan Verification. Langkah-langkah penyelesaian masalah tersebut sebenarnya merupakan pengembangan dari 4 langkah Polya.

Sementara itu, Krulik dan Rudnik (Lidinilah, 2009) mengenalkan lima langkah pemecahan masalah. Krulik dan Rudnik mengkhususkan langkah ini dapat diajarkan di sekolah dasar. Lima langkah tersebut adalah: (a) Read and Think (Membaca dan Berpikir). Mengidentifikasi fakta, mengidentifikasi pertanyaan, memvisualisasikan situasi, menjelaskan setting, menentukan tindakan selanjutnya, (b) Explore and Plan (Ekplorasi dan Merencanakan). Mengorganisasikan informasi, mencari apakah ada informasi yang sesuai/diperlukan, mencari apakah ada informasi yang tidak diperlukan, mengambar/ mengilustrasikan model masalah, membuat diagram, tabel, atau gambar, (c) Select a Strategy (Memilih Strategi). Menemukan/ membuat pola, bekerja mundur, coba dan kerjakan, simulasi atau eksperimen, penyederhanaan atau ekspansi, membuat daftar berurutan, deduksi logis, membagi atau mengkategorikan permasalahan menjadi masalah sederhana, (d) Find an Answer (Mencari Jawaban). Memprediksi atau estimasi, menggunakan kemampuan berhitung, menggunakan kemampuan aljabar, menggunakan kemampuan geometris, menggunakan kalkulator jika diperlukan, (e) Reflect and Extend (Refleksi dan Mengembangkan). Memeriksa kembali jawaban, menentukan solusi alternatif, mengembangkan jawaban pada situasi lain, mengembangkan jawaban (generalisasi atau konseptualisasi), mendiskusikan jawaban, menciptakan variasi masalah dari masalah yang asal.

Ruseffendi (1976) mengajukan 5 langkah dalam pemecahan masalah yang harus dilakukan yakni: (a) Menyajikan masalah dalam bentuk yang lebih jelas, (b) Menyatakan masalah dalam bentuk operasional (dapat dipecahkan), (c) Menyusun hipotesis-hipotesis alternatif dan prosedur kerja yang diperkirakan baik untuk dipergunakan dalam memecahkan masalah itu, (d) Mengetes hipotesis dan melakukan kerja untuk memperoleh 
hasilnya (pengumpulan data, pengolahan data, dan lain-lain), hasilnya mungkin lebih dari sebuah, (e) Memeriksa kembali (mengecek) apakah hasil yang diperoleh itu benar, mungkin memilih pula pemecahan yang paling baik.

Dalam penelitian ini menggunakan pendapat yang dikemukakan oleh Polya (Nuralam, 2009) bahwa langkah-langkah pemecahan masalah yakni memahami masalah, merencanakan penyelesaian, menyelesaikan masalah, dan melakukan pengecekan kembali semua langkah yang telah dikerjakan.

\section{Indikator Kemampuan Pemecahan Masalah}

Secara garis besar indikator kemampuan pemecahan masalah menurut Polya (Nuralam, 2009) sebagaimana pada Tabel 1.

\section{Problem Based Learning}

Arend (Trianto, 2009) bahwa Problem Based Learning adalah metode pembelajaran dimana siswa mengerjakan permasalahan yang otentik dengan maksud untuk menyusun pengetahuan mereka sendiri, mengembangkan inquiri, keterampilan dan percaya diri.
Problem Based Learning memiliki karakteristik sebagai berikut: (a) Pengajuan pertanyaan atau masalah harus autentik, jelas, mudah dipahami, luas dan sesuai tujuan pembelajaran serta bermanfaat, (b) Berfokus pada keterkaitan antar disiplin ilmu, (c) Penyelidikan autentik (nyata), (d) Menghasilkan produk dan memamerkannya, (e) Kolaboratif.

Kelebihan dari Problem Based Learning sebagai berikut: (a) Realistik dengan kehidupan siswa, (b) Konsep sesuai dengan kebutuhan siswa, (c) Memupuk sifat inquiry siswa, (d) Retensi konsep menjadi kuat, (e) Memupuk kemampuan pemecahan masalah.

Kekurangan dari Problem Based Learning sebagai berikut: (a) Perlu persiapan pembelajaran (alat, problem, konsep) yang kompleks, (b) Sulitnya mencari problem yang relevan, (c) Sering terjadi miss-konsepsi, (d) Memerlukan waktu yang cukup panjang.

Langkah-langkah pelaksanaan metode Problem Based Learning, dapat dilakukan sebagai berikut: (a) Perencanaan, yang mecakup beberapa hal seperti mempersiapkan siswa untuk dapat berperan self-directed problem solvers yang dapat berkolaborasi dengan pihak lain, menghadapkan siswa pada

Tabel 1 Indikator Kemampuan Pemecahan Masalah Menurut Polya Berdasarkan Langkah-langkah Pemecahan Masalah

\begin{tabular}{|c|c|c|}
\hline No & $\begin{array}{l}\text { Langkah Pemecahan } \\
\text { Masalah }\end{array}$ & Indikator \\
\hline 1 & $\begin{array}{l}\text { Memahami soal } \\
\text { (Understanding) }\end{array}$ & $\begin{array}{l}\text { Siswa harus memahami kondisi soal atau masalah yang ada pada soal tersebut, seperti: } \\
\text { - Data atau informasi apa yang dapat diketahui dari soal? } \\
\text { - Apa inti permasalahan dari soal yang memerlukan pemecahan? } \\
\text { - Adakah dalam soal itu rumus-rumus, gambar, grafik, tabel atau tanda-tanda } \\
\text { khusus? } \\
\text { - Adakah syarat-syarat penting yang perlu diperhatikan dalam soal? }\end{array}$ \\
\hline 2 & $\begin{array}{l}\text { Merencanakan } \\
\text { penyelesaian } \\
\text { (Planning) }\end{array}$ & $\begin{array}{l}\text { - Siswa harus dapat memikirkan langkah-langkah apa saja yang penting dan saling } \\
\text { menunjang untuk dapat memecahkan masalah yang dihadapinya } \\
\text { - Siswa harus mencari konsep-konsep atau teori-teori yang saling menun-jang dan } \\
\text { mencari rumus-rumus yang diperlukan }\end{array}$ \\
\hline 3 & $\begin{array}{l}\text { Menyelesaikan } \\
\text { Masalah (Solving) }\end{array}$ & $\begin{array}{l}\text { - Siswa telah siap melakukan perhitungan dengan segala macam data yang } \\
\text { diperlukan termasuk konsep dan rumus atau persamaan yang sesuai } \\
\text { - } \quad \text { Siswa harus dapat membentuk sistematika soal yang lebih baku } \\
\text { - } \quad \text { Siswa mulai memasukkan data-data hingga menjurus ke rencana peme-cahannya } \\
\text { - } \quad \text { Siswa melaksanakan langkah-langkah rencana }\end{array}$ \\
\hline 4 & $\begin{array}{l}\text { Melakukan Pengecekan } \\
\text { Kembali (Checking) }\end{array}$ & $\begin{array}{l}\text { Siswa harus berusaha mengecek ulang dan menelaah kembali dengan teliti setiap } \\
\text { langkah pemecahan yang dilakukannya }\end{array}$ \\
\hline
\end{tabular}


suatu situasi yang dapat mendorong mereka untuk mampu menemukan masalahnya, dan meneliti hakikat permasalahan yang dipersiapkan sambil mengajukan dugaan-dugaan serta rencana penyelesaian masalah, (b) Penyelidikan, meliputi kegiatan mengeksplorasi berbagai cara menjelaskan kejadian serta implikasinya dan mengumpulkan serta mendistribusikan informasi, (c) Penyajian hasil yaitu menyajikan temuan-temuan, (d) Tanya jawab/diskusi yang meliputi kegiatan menguji kelemahan dan keunggulan solusi yang dihasilkan, dan melakukan refleksi atas efektivitas seluruh pendekatan yang telah digunakan dalam penyelesaian masalah.

\section{Operasi Hitung Bilangan Pecahan}

Operasi hitung bilangan pecahan merupakan salah satu pokok bahasan di kelas V Sekolah Dasar. Salah satu bagian penting dalam materi ini menyangkut masalah soal cerita, yakni suatu permasalahan matematika yang disajikan dalam bentuk kalimat dan biasanya berhubungan dengan masalah sehari-hari. Oleh karena itu, penyelesaian masalah operasi hitung bilangan pecahan diselesaikan setelah melalui prosedur perumusan model/kalimat matematika.

\section{METODE PENELITIAN}

Penelitian ini dilakukan di SDN Mlowo Karangtalun 04 Kecamatan Pulokulon Kabupaten Grobogan, dengan subjek penelitian adalah siswa kelas V sebanyak 23 siswa yang terdiri dari 13 siswa laki-laki, dan 10 siswa perempuan. Jenis Penelitian ini adalah penelitian tindakan kelas model spiral yang dikemukakan oleh Kemmis dan Mc Taggart (Wiriaatmadja, 2005), dimana setiap siklus terdiri dari 3 tahapan yakni tahapan perencanaan, tahapan pelaksanaan yang dilaksanakan secara bersamaan dengan observasi, dan tahapan refleksi.
Jenis data yang digunakan dalam penelitian ini berupa data kualitatif dan kuantitatif. Data kualitatif yaitu data yang diperoleh langsung dari hasil pengamatan lembar observasi guru dan siswa dalam kegiatan belajar mengajar dengan penerapan Problem Based Learning. Sedangkan data kuantitatif diperoleh dari hasil tes evaluasi kemampuan pemecahan masalah operasi hitung bilangan pecahan. Data tersebut dianalisis dengan menggunakan teknik analisis deskripsi komparatif. Teknik ini dilakukan dengan cara membandingkan hasil penelitian pra siklus dan tiap siklus yang telah dilakukan.

Teknik pengumpulan data yang dilakukan pada penelitian ini adalah tes, dan observasi. Tes dalam penelitian ini menggunakan jenis tes subjektif yang diberikan kepada siswa untuk mengetahui kemampuan pemecahan masalah pada operasi hitung bilangan pecahan. Observasi dalam penelitian ini digunakan untuk mengamati aktivitas guru dan siswa pada proses pembelajaran Problem Based Learning.

Instrumen yang digunakan adalah soal tes, lembar observasi aktivitas siswa dan guru. Adapun untuk validitas soal tes maupun lembar evaluasi harus memenuhi validitas. Penelitian ini menggunakan validitas ahli, yaitu validitas yang didasarkan pada pertimbangan para ahli. Soal tes yang diberikan pada siswa sebelumnya telah mendapat persetujuan dari dosen pembimbing dan guru kelas V SDN Mlowo Karangtalun 04 Kecamatan Pulokulon Kabupaten Grobogan.

Peneliti menetapkan indikator kinerja, dimana indikator tersebut terbagi menjadi dua indikator yaitu indikator proses dan indikator hasil. Penelitian ini memberikan patokan indikator proses 85 persen dari jumlah keseluruhan kegiatan dari kegiatan pembelajaran Problem Based Learning. Sedangkan Indikator hasil dari penelitian ini 
adalah ketercapaian KKM pada hasil tes kemampuan siswa dalam pemecahan masalah, dimana KKM di sekolah adalah 63 dan KKM yang akan diberikan dalam penelitian ini adalah 65. Pemberian patokan keberhasilan 85 persen dari jumlah keseluruhan siswa dengan mencapai nilai $\geq 65$ berdasarkan hasil evaluasi tertulis siswa sebagai pencapaian indikator hasil.

\section{HASIL DAN PEMBAHASAN}

Hasil penelitian yang berkaitan dengan kemampuan pemecahan masalah operasi hitung bilangan pecahan pada siswa kelas V SDN Mlowo Karangtalun 04 Kecamatan Pulokulon Kabupaten Grobogan akan dianalisis dengan cara analisis deskriptif komparatif yaitu membandingkan hasil belajar siswa antar siklus. Pelaksanaan penelitian semua siklus akan dipaparkan secara bersamaan dan diperbandingkan sehingga akan diketahui perkembangan kemampuan pemecahan masalah siswa.

Hasil observasi awal menunjukkan bahwa proses belajar mengajar belum sepenuhnya optimal, penyampaian materi masih menggunakan metode ekspositori yang menekankan penggunaan rumus dan latihan soal yang bersifat rutin, sehingga berdampak pada kemampuan pemecahan masalah siswa. Bentuk solusi dari permasalahan ini adalah melalui penerapan Problem Based Learning.

Kemampuan pemecahan masalah siswa pada siklus 1 masih belum optimal. Namun, keaktifan siswa dalam pembelajaran siklus 1 mengalami peningkatan dibandingkan sebelum tindakan kelas dilaksanakan. Pada awal siklus 1 siswa masih belum terbiasa menggunakan pembelajaran Problem Based Learning karena metode ini jarang digunakan oleh guru, sehingga ada beberapa siswa yang belum berani dan masih malu-malu untuk menanyakan hal-hal yang kurang jelas, ada siswa yang ditunjuk sebagai perwakilan kelompok namun belum berani maju ke depan mempresentasikan hasil pemecahan masalah yang dilakukan dalam kelompoknya karena takut salah. Ketika berlangsungnya diskusi kelompok, tiap-tiap kelompok perlu diberi jarak sehingga tidak dapat berbincang. Pengamatan pembelajaran siklus 1 , peneliti masih belum sepenuhnya melaksanakan semua yang sudah direncanakan. Peneliti belum optimal dalam mengarahkan dan mendampingi siswa dalam kelompok. Pada pertemuan keempat peneliti kurang mampu dalam pembagian waktu. Peneliti dan siswa harus bekerjasama lebih baik lagi dalam pembelajaran di siklus 2 agar penerapan Problem Based Learning dapat terlaksana dengan efektif.

Keadaan siswa pada siklus 2 ini jauh lebih baik lagi. Proses belajar mengajar berjalan lebih baik. Kerja sama siswa pada tiaptiap kelompok jauh lebih maksimal. Antusias siswa dalam memecahkan masalah yang diberikan lebih meningkat. Hal ini tampak pada hasil diskusi kelompok yang meningkat. Perhatian siswa sudah terfokus dan kegiatan berbicara sendiri serta bergurau sudah tidak ada lagi. Secara umum siswa dapat mengikuti proses pembelajaran dengan baik, siswa senang, siswa aktif, siswa percaya diri, siswa menunjukkan minat belajar yang baik, perhatian siswa fokus dan siswa mampu bekerjasama dalam kelompoknya. Sedangkan pada siklus 2, peneliti menyadari benar kekurangan-kekurangan pada pembelajaran siklus 1 sehingga peneliti lebih optimal dalam mengarahkan dan membimbing siswa. Semua kegiatan inti yang direncanakan sudah dilaksanakan dan peneliti tidak mengulang lagi kesalahannya dan mampu melaksanakan dengan baik.

Adapun untuk lebih memperjelas peningkatan kemampuan pemecahan masa- 
lah sebelum dan sesudah pelaksanaan pembelajaran dengan penerapan Problem Based Learning maka dipaparkan hasil pengolahan nilai hasil tes evaluasi kemampuan pemecahan masalah siswa dalam bentuk tabel 2 , berikut ini.

Tabel 2 Perolehan Nilai Tes Evaluasi Kemampuan Pemecahan Masalah Antar Siklus

\begin{tabular}{|c|c|c|c|}
\hline No. Kategori & Pra Siklus & Siklus 1 & Siklus 2 \\
\hline 1. Nilai terendah & 29 & 50 & 56 \\
\hline 2. Nilai tertinggi & 96 & 100 & 100 \\
\hline 3. Rata-rata nilai & 62,87 & 74,95 & 84,43 \\
\hline
\end{tabular}

Dari data tabel 2 dapat dijelaskan bahwa terjadi peningkatan kemampuan pemecahan masalah operasi hitung bilangan pecahan pada dari pra siklus yaitu sebelum penerapan Problem Based Learning dan setelah penerapan Problem Based Learning pada siklus 1 dan siklus 2 . Terjadi peningkatan nilai terendah siswa yaitu dari 29 menjadi 56 pada siklus 2 terjadi kenaikan sebesar 27 poin, demikian juga pada nilai tertinggi siswa juga terjadi peningkatan dari 96 pada pra siklus menjadi 100 pada siklus 2 atau 4 poin sedangkan rata-rata nilai siswa secara klasikal menunjukkan peningkatan yaitu dari 62,87 pada pra siklus menjadi 84,43 pada akhir pembelajaran siklus II atau terjadi peningkatan sebesar 21,56 poin.

Keberhasilan atau kegagalan penerapan Problem Based Learning dalam meningkatkan kemampuan pemecahan masalah operasi hitung bilangan pecahan dapat dilihat pada paparan tabel 3 tentang ketuntasan belajar siswa.

Dari paparan data pada tabel 3 dapat disimpulkan bahwa telah terjadi peningkatan jumlah siswa yang tuntas tes evaluasi kemampuan pemecahan masalah dari pra siklus sampai dengan pembelajaran siklus 2 . Ketuntasan klasikal pada pra siklus adalah
39 persen siswa tuntas dan 61 persen siswa tidak tuntas, pada siklus I sebesar 74 persen siswa tuntas dan 26 persen siswa tidak tuntas. Sedangkan pada siklus II siswa mengalami ketuntasan belajar sebesar 87 persen. Dari siklus 2 ini ketercapaian indikator keberhasilan sangat baik, karena melebihi standar indikator keberhasilan yang sudah ditentukan, yaitu 85 persen maka tidak perlu diadakan tindakan siklus berikutnya.

Berdasarkan hasil analisis data yang dilakukan menunjukkan bahwa penerapan Problem Based Learning dapat meningkatkan kemampuan pemecahan masalah operasi hitung bilangan pecahan pada siswa kelas $\mathrm{V}$ SDN Mlowo Karangtalun 04 Kecamatan Pulokulon Kabupaten Grobogan. Hal ini sesuai dengan teori Arend (Trianto, 2009) yang mengemukakan bahwa salah satu kelebihan Problem Based Learning adalah meningkatkan kemampuan pemecahan masalah.

Kondisi ini bisa terjadi karena proses pembelajaran lebih fokus pada aktivitas siswa. Siswa diberi kesempatan yang luas untuk melakukan pembelajaran secara sistematis melalui kegiatan identifikasi masalah, merencanakan penyelesaian, pengumpulan data, analisis data, pemecahan masalah, pembahasan pemecahan sampai mendapatkan hasil pemecahan masalah yang paling efektif. Selain itu kegiatan kerja dalam kelompok juga memberi peluang siswa bisa bekerja sama dalam memikirkan sesuatu sehingga ide mereka lebih beragam. Kondisi inilah yang akhirnya membuat siswa lebih aktif dan kritis dalam pembelajaran sehingga proses belajar berjalan baik dan akhirnya hasil belajarnya juga baik.

\section{SIMPULAN}

Berdasarkan hasil penelitian dan pembahasan, maka dapat disimpulkan bahwa 
melalui penerapan Problem Based Learning dapat meningkatkan kemampuan pemecahan masalah operasi hitung bilangan pecahan pada siswa kelas V SDN Mlowo Karangtalun 04 Kecamatan Pulokulon Kabupaten Grobogan. Kemampuan pemecahan masalah dengan penerapan Problem Based Learning mengalami peningkatan dari siklus 1 sampai siklus 2, pada siklus 1 siswa yang tuntas KKM sebanyak 17 siswa dengan persentase 74 persen dari 23 siswa, dan pada siklus 2 terjadi peningkatan sebanyak 20 siswa dengan persentase 87 persen dari 23 siswa dengan KKM 65 dan indikator kinerja 85 persen.

\section{DAFTAR PUSTAKA}

Amir, T. 2010. Inovasi Pendidikan Melalui Problem Based Learning. Jakarta: Kencana Media Group.

Depdikbud. 2011. Pemecahan Masalah Terkait Pembelajaran Matematika di Sekolah Dasar. Modul Bahan Pendidikan dan Latihan Guru Pasca-Uji Kompetensi Awal: Kementerian Pendidikan dan Kebudayaan

Hamid, S. 2011. Metode Edutainment. Yogya-karta: Diva Press.

Lidinillah, D. A. M. 2009. Heuristik dalam Pemecahan Masalah Matematika dan Pembelajarannya di Sekolah Dasar. Bandung: UPI Bandung.

Nuralam. 2009. Pemecahan Masalah Sebagai Pendekatan dalam Belajar Matematika. Jurnal Edukasi, Vol. V, No. 1.
Supartinah. 2012. Upaya Meningkatkan Kemampuan Siswa dalam Melakukan Operasi Hitung pada Pecahan Melalui Pembelajaran Matematika Berbasis Masalah. Skripsi: FIP UPI.

Supinah. 2010. Pembelajaran Berbasis Masalah Matematika SD. Modul Matematika SD Program Bermutu: Kementerian Pen-didikan Nasional.

Tim Pengembang Ilmu Pendidikan FIP-UPI. 2007. Hakikat Matematika dan Pembelajaran Matematika di SD. Bandung: PT Imperial Bhakti Utama.

Trianto. 2009. Mendesain Model Pembelajaran Invotif-Progresif. Jakarta: Prenada Media Group.

Wahyudi. 2011. Peningkatan Kemampuan Menyelesaikan Soal Cerita Melalui Penerapan Problem Based Learning dalam Pembelajaran Matematika. Jurnal: UKSW

Walle, J.A. 2006. Matematika Sekolah Dasar dan Menengah Jilid 2. Jakarta: Penerbit Erlangga.

Wiriaatmadja, R. 2005. Metode PTK untuk Meningkatkan Kinerja Guru dan Dosen. Bandung: Program Pasca Sarjana UPI dengan PT Remaja Rosdakarya. 